\title{
ASESMEN OTENTIK BERBASIS TEKNOLOGI PLICKERS BAGI SISWA SD MASA PANDEMI COVID-19
}

\author{
Eko Purwanti $^{1 *}$, Sri Sulistyorini ${ }^{2}$, Nugraheti Sismulyasih $^{3}$, Trimurtini $^{4}$, \\ Isa Ansori ${ }^{5}$, Marjuni $^{6}$ \\ 1,2,3,4,5,6 Jurusan PGSD FIP, Universitas Negeri Semarang \\ Email: purwanti17@mail.unnes.ac.id
}

\begin{abstract}
Assessment of learning outcomes often referred to by students as replays becomes something scary for students. There needs to be effort and innovation to change the stigma of students towards replay. If the replay is packaged interestingly, then the student will have enthusiasm and motivation towards the replay because the student feels as a pleasant thing so it will have a positive impact on the student's learning outcomes. The purpose of this community service activity is to improve the skills of elementary school teachers in conducting assessment analysis of learning results based on information technology. Especially intended to develop skills to elementary school teachers in the analysis of learning results based on plickers technology through training and mentoring activities. Training materials include the introduction of plickers, technical development of plickers, and the practice of using plickers. A sample of 30 teachers at SD Ngaliyan 01 was taken purposive random sampling. Training methods include q\&A, discussions, assignments, portfolios, pretes, posts and preparation of follow-up plans. The results of community activities show the following: the average attendance of participants was $96.3 \%$ with full participation. Pretest \& posttest results showed participants an average of 59.17. The average postest was 89.8. The average community service team attendance is $100 \%$. Presentation of material is carried out by discussion method, assignment, demonstration and lecture with a handout of serving material. 100\% certificate kepesertan workshop 36 JP. There is an increase in participants' scores from pretest to postest, it can be concluded that there is a development of the skills of elementary school teachers in the assessment of student learning results based on plickers technology in Ngaliyan Sub-district of Semarang.
\end{abstract}

Keywords: assessment analysis; learning results; plickers technology

\begin{abstract}
Abstrak
Asesmen hasil belajar yang sering disebut oleh siswa sebagai ulangan menjadi sesuatu hal yang menakutkan bagi siswa. Perlu adanya upaya dan inovasi untuk mengubah stigma siswa terhadap ulangan. Apabila ulangan dikemas dengan menarik, maka siswa akan memiliki antusias dan motivasi terhadap ulangan karena siswa merasakan sebagai hal yang menyenangkan sehingga akan berdampak positif terhadap hasil belajar siswa. Tujuan dari kegiatan pengabdian masyarakat ini adalah meningkatkan keterampilan guru sekolah dasar (SD) dalam melakukan analisis asesmen hasil belajar berbasis teknologi informasi. Khususnya dimaksudkan mengembangkan keterampilan kepada guru-guru SD dalam analisis asesmen hasil belajar berbasis teknologi plickers melalui kegiatan pelatihan dan pendampingan. Materi pelatihan meliputi pengenalan plickers, teknis pengembangan plickers, dan praktik penggunaan plickers. Sampel kegiatan pengabdian masyarakat ini sebanyak 30 guru di SD Ngaliyan 01 yang diambil secara purposive random sampling. Metode pelatihan meliputi tanya jawab, diskusi, penugasan, portofolio, pretes, postes dan penyusunan rencana tindak lanjut. Hasil kegiatan masyarakat menunjukkan hal-hal sebagai berikut: rata-rata kehadiran peserta $96,3 \%$ dengan partisipasi penuh. Hasil pretest \& postest peserta menunjukkan rata- rata 59,17. Adapun perolehan nilai rata- rata pada postest adalah 89,8. Kehadiran tim pengabdian masyarakat rata-rata $100 \%$. Penyajian materi dilaksanakan dengan metode diskusi, penugasan, demonstrasi dan ceramah dilengkapi handout materi
\end{abstract}


sajian. Diberikan sertifikat kepesertaan workshop setara 36 JP. Terjadi peningkatan nilai peserta dari pretest ke postest, dapat disimpulkan bahwa ada pengembangan keterampilan guru SD dalam analisis asesmen hasil belajar siswa berbasis teknologi plickers di Kecamatan Ngaliyan Kota Semarang.

Kata Kunci: analisis asesmen; hasil belajar; teknologi plickers

\section{PENDAHULUAN}

Persebaran Covid 19 yang begitu cepat di berbagai negara telah memaksa masyarakat dunia untuk melihat fakta bahwa dunia sedang berubah. Tidak hanya itu, mereka harus melihat pula bagaimana perubahan-perubahan di bidang sosial, ekonomi, politik, hukum hinga bidang pendidikan ikut berduka di tengah-tengah krisis akibat sebaran Covid-19. Pademmi covid-19 telah memaksa masyarakat untuk mengubah makna, pola hidup dan kehidupan sehari-hari. Semua Negara tergerak membuat kebijakan untuk mengantisipasi perlambatan dan pencegahan efek sebaran virus covid19.

Dampak sebaran virus covid-19 ini, telah memaksa semua kebijakan social distancing, atau dikenal pula physical distancing (untuk menjaga jarak pisik), dilakukan sebagai upaya unuk meminimalisir dan mencegas sebaran virus copid-19. Secara umum, kebijakan itu dibuat sebagai upaya memperlambat dari laju sebaran virus copid-19 di lingkungan masyarakat. Untuk hal itu WHO, menggunakan beberapa istilah yakni social distancing, physical distancing, karantina dan isolasi. Namun ada juga PSBB (Pembatasan Sosial Berskala Besar). Salah satu upaya pencegahan sebaran copid-19 di lingkungan pendidikan, Kementrian Pendidikan dan Kebudayaan, merespon dengan kebijakan "belajar dari rumah", melalui pembelajaran daring dan disusul dengan kebijakan peniadaan Ujian Nasional untuk tahun ini (Kemendikbud, 2020).

Fenomena demikian, menjadi catatan tersendiri bagi dunia pendidikan, yang menuntut harus siap mengajar dan belajar secara online/daring yang syarat kompetensi, tepat, cermat dan cepat (Pemerintahan RI, 2007). Disisi lain kompetensi, system, dan teknis belum mendukung sepenunya untuk itu. Dikarenakan selama ini pembelajaran dilaksanakan oleh guru dan dosen terbiasa dengan pola lama dengan teacher centred, pembelajaran daring baru sampai pada wacana sebagai perangkat teknis, belum mengarah pada media pengubah cara berfikir dan bertindak, sebagai paradingma pembelajaran berbasis student centre, untuk menjadikan siswa kreatif, inovatif yang menghasilkan karya, wawasan pembentukan siswa menjadi pembelajar sepanjang hayat (Undang-Undang Republik Indonesia, 2003).

Guru dalam tugasnya tidak hanya memiliki kewajiban mendidik, mengajar, membimbing namun juga melaksanakan tugas administrasi kelas. Guru mengalami beberapa kendala dalam melaksanakan administrasi kelas salah satunya yaitu menganalisis evaluasi hasil belajar yang tidak sempat untuk dilakukan secara menual 
mengingat keterbatasan waktu dan tenaga (Astuti, 2012).

Kemampuan siswa dalam beberapa bagian materi pembelajaran dapat dideteksi keberhasilannya dari tiap butir soal dan jawaban yang dapat dipecahkan oleh siswa. Analisis evaluasi hasil belajar menjadi acuan guru dalam melakukan tindak lanjut terhadap siswa dan materi yang telah diajarkan. Analisis evaluasi hasil belajar memiliki peranan penting dalam pembelajaran dan harus dikembangkan agar memiliki efektivitas yang tinggi (Basiroh, 2017).

Di era pandemi, perlu adanya inovasi berbasis teknologi. Solusi pengembangan analisis evaluasi hasil belajar berbasis IT adalah dengan menggunakan plickers. Dengan adanya pengembangan ini, guru akan merasa sangat terbantu karena pada plickers masing-masing siswa memiliki barcode masing-masing sehingga meminimalisir kecurangan (Chng, 2018). Setelah melaksanakan ulangan, skor siswa akan keluar langsung. Analisis personal dan klasikal siswa juga dapat langsung terlihat pada layar monitor melalui scoresheet sehingga guru dapat dengan mudah menganalisis evaluasi hasil belajar. Selain itu, plickers juga memnuhi standar social distanction.

Evaluasi hasil belajar yang sering disebut siswa sebagai ulangan menjadi sesuatu hal yang menakutkan bagi siswa. Perlu adanya upaya dan inovasi untuk mengubah stigma 3istinct siswa terhadap ulangan. Apabila ulangan dikemas dengan menarik, maka siswa akan memiliki antusias dan motivasi terhadap ulangan karena siswa merasakan sebagai hal yang menyenangkan sehingga akan berdampak positif terhadap hasil belajar siswa (Susanto, 2014).

Berdasarkan kenyataannya dilapangan yang terjadi saat ini adalah guru hanya sekedar memberikan feedback ulangan berupa remedial dan pengayaan sehingga tidak ada analisis butir soal dan lain sebagainya. Analisis evaluasi hasil belajar bertujuan untuk mendeteksi materi yang mayoritas belum dipahami siswa sehingga guru dapat memberikan penjelasan lebih mendalam.

Transformasi pengembangan analisis evaluasi hasil belajar berbasis teknologi menggunakan plickers menjadi salah satu jawaban terhadap beragam persoalan dunia pendidikan yang diidentifikasi bersumber dari gagalnya pendidikan dalam asesmen yang monoton sehingga antusiasme siswa terhadap penilaian rendah yang akan berdampak pada hasil belajar (Horoepoetri, 2003).

\section{TINJAUAN LITERATUR}

Proses pembelajaran tidak akan terlepas dari penilaian. Kegiatan asesmen dapat menjadi tolak ukur keberhasilan suatu proses pembelajaran. Hood dan Johnson (Muri Yusuf, 2015), berdasarkan Standards for Educational and Psychological Test berpendapat asesmen mengacu pada berbagai metode yang digunakan untuk mengetahui karakteristik individ, program atau objek. 
Asesmen atau penilaian diartikan sebagai suatu kegiatan pengumpulan data dan atauu informasi secara sistematis tentang orang ataupun komponen pembelajaran sebagai usaha untuk menganalisis karakteristik komponen dalam pembelajaran, kelebihan dan kelemahan, proses pelaksanaan dan hasil yang dicapai sesuai dengan tujuan yang telah dibuat. Informasi mengenai kemajuan prestasi dan pencapaian peserta didik selama proses belajar dapat diketahui melalui proses asesmen yang dilakukan oleh guru. Seiring berkembangnya zaman, proses asesmen dapat dilakukan dengan memanfaatkan teknologi informasi salah satunya menggunakan aplikasi plickers.

Aplikasi plickers merupakan aplikasi yang sering digunakan untuk proses penilaian dengan bentuk soal multiple choice atau pilihan ganda. Plickers memiliki kelebihan dan kelemahan sebagai aplikasi untuk melakukan proses penilaian dalam pembelajaran. Penerapan aplikasi plickers sangat membantu guru untuk menganalisis hasil belajar serta dapat menarik siswa untuk mengikuti penilaian harian yang dilaksanakan oleh guru. Berikut beberapa penelitian terkait penerapan aplikasi plickers dalam proses pembelajaran.

Meita Sari Setyani dalam Jurnal IT-EDU tahun 2020 (132-139) dengan judul Penerapan Model Kooperatif Tipe Group Invertigation Menggunakan Media Plickers Untuk Meningkatkan Critical Thinking Skill dan Hasil Belajar Siswa. Hasil penelitian menunjukkan bahwa nilai rata-rata belajar siswa kelas kontrol sebesar 73,77 dan hasil belajar siswa kelas eksperimen sebesar 83,63. Pemanfaatan media plickers dalam pembelajaran juga dapat memberikan manfaat dalam kegiatan belajar mengajar serta siswa belajar dalam keadaan menyenangkan.

Lusi Yulanda dan Zafri dalam Jurnal Kapita Selekta Geografi volume 2 nomor 4 p-ISSN: 2622-4925, e-ISSN: 2622-4933 Mei 2019 dengan judul Pemanfaatan Aplikasi Plickers Pada Mata Pelajaran Sejarah Kelas X SMAN 01 IV Nigari Baying Utara. Hasil penelitian menunjukkan guru SMAN 01 IV Nagari Baying Utara sudah dapat memanfaatkan aplikasi plickers untuk ulangan harian maupun kuis pada mata pelajaran sejarah dengan baik dan benar.

\section{METODE PELAKSANAAN}

Metode yang digunakan untuk mencapai tujuan kegiatan ini adalah dengan memberikan pelatihan-pelatihan pengembangan keterampilan guru menganalisis evaluasi hasil belajar berbasis teknologi plickers. Metode yang digunakan dalam pelatihan ini adalah pre tes dan post tes pemahaman guru tentang plickers. Selain itu, peneliti melakukan tindak lanjut dengan cara memantau hasil belajar siswa yang diperoleh dari penggunaan kartu plickers.

Untuk mengetahui pemahaman guru terhadap aplikasi plickers beserta penggunaannya, maka diiukur menggunakan beberapa aspek yang tertuang dalam instrument. Pengabdi 
menggunakan google form untuk membuat instrument dapat diakses pada link. Kemudian menganalisis hasil pre test dan post test dengan menentukan mean, modus, median.

\section{HASIL DAN PEMBAHASAN}

Pengabdian dilakukan menggunakan daring karena situasi istinct yang baru saja berlangsung. Dampak sebaran virus covid 19 ini, telah memaksa semua kebijakan social distancing, atau dikenal pula physical distancing (untuk menjaga jarak pisik), dilakukan sebagai upaya unuk meminimalisir dan mencegas sebaran virus covid-19. Secara umum, kebijakan itu dibuat sebagai upaya memperlambat dari laju sebaran virus copid-19 di lingkungan masyarakat. Untuk hal itu WHO, menggunakan beberapa istilah yakni social distancing, physical distancing, karantina dan isolasi. Namun ada juga PSBB (Pembatasan Sosial Berskala Besar). Salah satu upaya pencegahan sebaran covid-19 di lingkungan pendidikan, Kementrian Pendidikan dan Kebudayaan, merespon dengan kebijakan "belajar dari rumah", melalui pembelajaran daring dan disusul dengan kebijakan peniadaan Ujian Nasional untuk tahun ini (Kemendikbud, 2020).

Pemberlakuan kebijakan social distancing, physical distancing, kemudian menjadi dasar kebijakan pendidikan dengan 'belajar dari rumah", dengan penggunaan dan pemanfaatan internet berlaku secara serentak dan tiba-tiba, membuat kepanikan para pendidik siswa dan mahasiswa merasa kaget termasuk orang tua mururid dan bahkan semua orang yang berada di rumah. Walaupun pembelajaran IT daring sudah diberlakukan sejak beberapa tahun lalu. Namun, pembelajaran daring kali ini berlangsung sebagai efek kejut dari sebaran virus covid-19, membuat kepanikan dan kaget di hampir semua lapisan mansyarakat, wilayah, kedinasan dari desa, kecamatan, kabupaten/kota, provinsi, pusat bahkan dunia internasional. Kegiatan pengabdian masyarakat dimulai dari melaksanakan presensi menggunakan zoho form sebagai inovasi baru dalam melakukan presensi peserta dengan nilai akurasi yang tinggi karena terdapat tanda tangan yang harus diisi oleh peserta sehingga kontribusi kehadiran peserta pada saat workshop dapat dipertanggungjawabkan kebenarannya. Selanjutnya teknis pelaksanaan acara dan penyampaian materi workshop dilakukan melalui zoom clouds meeting sehingga ketika diadakan kebijakan blended learning guru sudah memiliki kesiapan.

Blended Learning merupakan suatu pendekatan yang digunakan dalam pembelajaran untuk mengintegrasikan pembelajaran tatap muka dan pembelajaran maya, tersedia ragam pilihan fasilitas komunikasi yang dapat digunakan oleh para tengaga pendidik dan peserta didik(Rooney, 2003), Pelaksanaan pendekatan ini memungkinkan penggunaan sumber belajar online, terutama yang berbasis web tanpa meninggalkan tatap muka. Dengan pelaksanaan belended learning 
ini, pembelajaran berlangsung lebih bermakna karena keragaman sumber belajar yang mungkin diperoleh

Kegiatan evaluasi asesmen hasil belajar menggunakan teknologi plickers ini masih dapat digunakan apabila sekolah mengadakan kebijakan blended learning yang memodifikasi antara pertemuan tatap muka dan pembelajaran daring dengan tetap mematuhi istinct kesehatan.

Kegiatan evaluasi menggunakan plickers ini merupakan alternatif untuk melaksanakan evaluasi dengan tetap mengedepankan protokol kesehatan terutama dalam aspek social distanctin karena pada saat guru melakukan barcode ketika siswa menjawab jaraknya harus jauh. Bahkan barcode tidak dapat terdeteksi apabila dibidik dengan radius jarak dekat. Oleh karena itu, plickers ini masih sangat efektif untuk diterapkan pada saat pembelajaran blended learning (Yulanda, 2019).

Plickers akan menunjukkan hasil evaluasi siswa secara real karena dalam praktik pembelajaran daring pada saat ini melalui google form, google classroom, quizizz dan lain sebagainya, banyak siswa yang mendapatkan bantuan dari orangtua pada saat pengerjaan soal. Hal ini tentu menimbulkan tidak validnya data seberapa besar pemahaman siswa dalam pembelajaran dan prestasi hasil belajar siswa tidak terukur secara valid.

Dari perwakilan guru dapat berkontribusi untuk sekolahnya sebagai influence atau orang yang berdampak baik itu bagi teman sejawat maupun instansi untuk mengembangkan analisis asesmen hasil belajar yang berbasis teknologi plickers. Output dalam pelatihan ini, kader guru yang mengikuti pelatihan dapat menjadi pelopor sekolah dalam melaksanakan analisis asesmen hasil belajar berbasis plickers. Hal ini menjadi inovasi sekaligus ide cemerlang untuk menjawab dunia pendidikan khususnya dalam pengadministrasian analisis asesmen hasil belajar yang selama ini kurang optimal dilakukan oleh guru karena keterbatasan dalam berbagai aspek. Sehingga guru pelopor tersebut dapat mengajarkan pada guru lain bahkan guru- guru di sekolah lain.

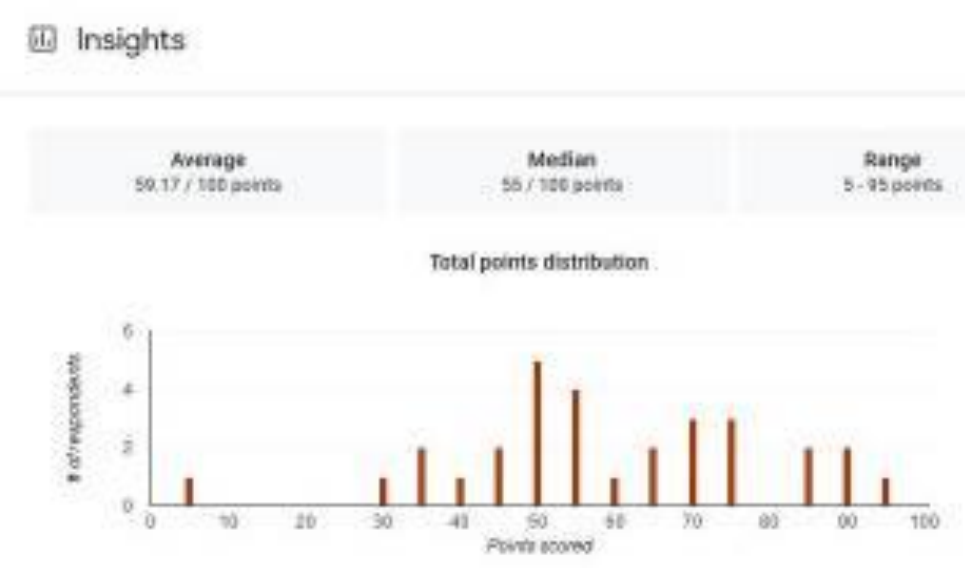

Gambar 1. Grafik Perolehan Skor Pre Test 


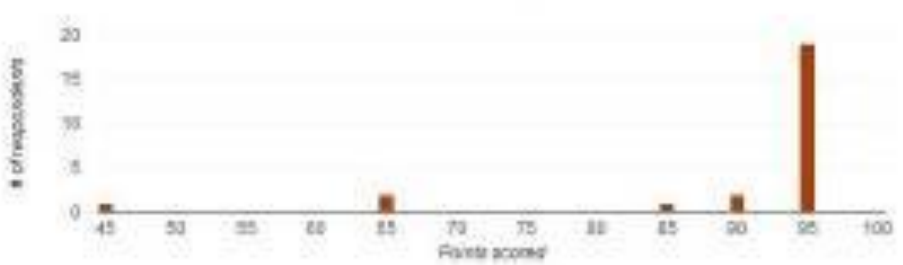

Gambar 2. Grafik Perolehan Skor Post Test

Tabel 1. Perolehan Skor Pre test dan Post Test

\begin{tabular}{|c|c|c|}
\hline Responden & Pre Test & Post Test \\
\hline $\mathrm{R} 1$ & $30 / 100$ & $85 / 100$ \\
\hline $\mathrm{R} 2$ & $75 / 100$ & $95 / 100$ \\
\hline R3 & $5 / 100$ & $45 / 100$ \\
\hline $\mathrm{R} 4$ & $40 / 100$ & $95 / 100$ \\
\hline R5 & $75 / 100$ & $95 / 100$ \\
\hline R6 & $45 / 100$ & $95 / 100$ \\
\hline R7 & $85 / 100$ & $95 / 100$ \\
\hline $\mathrm{R} 8$ & $50 / 100$ & $65 / 100$ \\
\hline R9 & $35 / 100$ & $95 / 100$ \\
\hline R10 & $50 / 100$ & $95 / 100$ \\
\hline R11 & $45 / 100$ & $95 / 100$ \\
\hline R12 & $50 / 100$ & $95 / 100$ \\
\hline R13 & $55 / 100$ & $95 / 100$ \\
\hline R14 & $55 / 100$ & $95 / 100$ \\
\hline R15 & $70 / 100$ & $95 / 100$ \\
\hline R16 & $65 / 100$ & $95 / 100$ \\
\hline R17 & $65 / 100$ & $95 / 100$ \\
\hline R18 & $85 / 100$ & $90 / 100$ \\
\hline R19 & $90 / 100$ & $95 / 100$ \\
\hline R20 & $90 / 100$ & $95 / 100$ \\
\hline $\mathrm{R} 21$ & $75 / 100$ & $85 / 100$ \\
\hline R22 & $90 / 100$ & $95 / 100$ \\
\hline R23 & $50 / 100$ & $95 / 100$ \\
\hline R24 & $55 / 100$ & $65 / 100$ \\
\hline R25 & $70 / 100$ & $95 / 100$ \\
\hline R26 & $55 / 100$ & $95 / 100$ \\
\hline R27 & $60 / 100$ & $90 / 100$ \\
\hline
\end{tabular}

Sarwahita : Jurnal Pengabdian Kepada Masyarakat Vol. 18 No. 1 Tahun 2021 |7 


\begin{tabular}{ccc}
\hline Responden & Pre Test & Post Test \\
\hline R28 & $35 / 100$ & $95 / 100$ \\
\hline R29 & $50 / 100$ & $90 / 100$ \\
\hline R30 & $70 / 100$ & $90 / 100$ \\
\hline
\end{tabular}

Berdasarkan grafik dan tabel di atas, maka perolehan hasil skor pretest dan post test mengalami peningkatan yang sangat signifikan. Data pretest semula memiliki median 55 sedangkan skor post test memiliki nilai 95. Dengan demikian, dapat disimpulkan bahwa workshop plickers memiliki keberhasilan yang optimal terlihat dari progress nilai pre test dan post tes.

Kegiatan asesmen menggunakan teknologi plickers akan memunculkan hasil evaluasi siswa secara real karena dalam praktik pembelajaran daring pada saat ini melalui google form, google classroom, quizizz dan lain sebagainya, banyak siswa yang mendapatkan bantuan dari orangtua pada saat pengerjaan soal. Hal ini tentu menimbulkan tidak validnya data seberapa besar pemahaman siswa dalam pembelajaran dan prestasi hasil belajar siswa tidak terukur secara valid.

\section{Insights}

Average

0) oporints

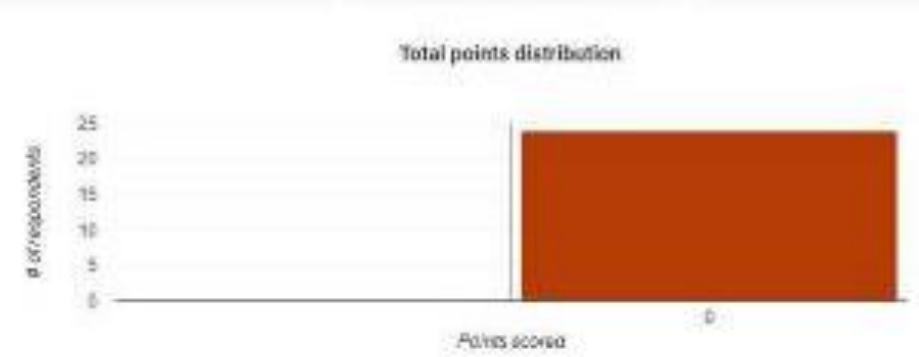

Gambar 3. Angket Evaluasi Kegiatan Workshop

Selain keberhasilan secara materi, terbukti juga melalui angket evaluasi kegiatan yang terlihat pada gambar di atas. Berdasarkan data di atas maka peserta workshop memiliki pemahaman yang tinggi serta memiliki respon baik terhadap workshop plickers yang telah dilaksanakan.

Guru tidak hanya memperoleh materi namun juga guru melakukan simulasi praktik secara nyata. Kegiatan dilakukan dengan pendampingan yang optimal sehingga guru dapat melaksanakan dengan mudah. Melalui penyusunan draft proyek yang terdapat langkah- langkah beserta contoh maka guru dapat mengoperasikan dengan mudah. Hasil kerja para peserta workshop didokumentasikan melalui tugas proyek yang dikerjakan sdengan 
cara men sreenshoot bukti praktik plickers yang telah dilaksanakan.

Dengan demikian, dari segi efektivitas dan efisiensi plickers sangat tepat digunakan terutama pada kondisi 9istinct seperti sekarang ini karena kegiatan evaluasi menggunakan plickers ini merupakan 9istinction untuk melaksanakan evaluasi dengan tetap mengedepankan protokol kesehatan terutama dalam aspek social distinction karena pada saat guru melakukan barcode ketika siswa menjawab jaraknya harus jauh. Bahkan barcode tidak dapat terdeteksi apabila dibidik dengan radius jarak dekat.

\section{PENUTUP}

Kegiatan pengabdian masyarakat ini adalah pengembangan keterampilan guru menganalisis asesmen hasil belajar berbasis teknologi plickers untuk meningkatkan kapabilitas guru. Peningkatan keterampilan guru melalui pelatihan pengembangan keterampilan guru menganalisis asesmen hasil belajar berbasis teknologi plickers diharapkan dapat menjadi solusi permasalahan dalam dunia pendidikan terutama dalam analisis asesmen hasil belajar yang rumit apabila dikerjakan secara manual serta membutuhkan waktu yang lama.

Metode pelatihan meliputi: pretes, postes, tanya jawab, diskusi, penugasan, portofolio, dan penyusunan rencana tindak lanjut. Dengan demikian tujuan pengabdian masyarakat ini meningkatkan keterampilan guru menganalisis asesmen hasil belajar berbasis teknologi plickers di SD
Ngaliyan 01, Kecamatan Ngaliyan Kota Semarang.

Saran yaitu sesuai dengan tema kegiatan pengabdian ini, kepakaran yang diperlukan diantaranya kepakaran dalam bidang pengembangan kurikulum dan teknologi. Perlunya pendampingan berkelanjutan untuk menjaga kebermanfaatan teknologi plickers, serta perlunya pelatihan sejenis di tempat lain mengingat manfaat teknologi plickers yang sangat besar.

\section{DAFTAR PUSTAKA}

Astuti, W. W., \& Dkk. (2012). Pengaruh Motivasi Belajar Dan Metode Pembelajaran terhadap Hasil Belajar IPS Terpadu Kelas VIII SMP PGRI 16 Brangsong Kabupaten Kendal. Economic Education Analysis Journal, 1(2),

Basiroh, U. (2017). Peningkatan Hasil Belajar dan Imtak pada Materi Rendah Hati, Hemat, dan Sederhana Melalui 3 Steps Of Role Playing Based On Daily Short Story Kelas VIII. Jurnal Profesi Keguruan, 3(1), 81.

Chng, Lena \& Rachel Gurvicth. (2018). Using Plickers as an Assessment Tool in Health and Physical Education Settings. Journal of Physical Education, Recreation \& Dance. 89:2,19-25.

Horoepoetri. 2003. Peran Serta Masyarakat dalam Mengelola Lingkungan. Jakarta: Walhi 
Kemendikbud, (2020). Cegah Sebaran Covid-19 di Satuan Pendidikan, Kemendikbud Gandeng Swasta Siapkan Solusi Belajar Daring (Siaran Pers BKH Kemendikbud Nomor: 054/SIPRES/A6/ III/2020. 15 Maret 2020). Dipeperoleh pada 15 April 2020, dari situs mendikbud.go.id: https:// www. Kemendikbud.go.id

Permendiknas No. 41 tahun 2007 tentang Standar Proses. Jakarta: Pemerintahan RI.

Rooney, J. E. (2003). Blended learning opportunities to enhance educational programming and meetings. Association Management, Scientific Research.
An Academic Publisher. 55(5), 2632.

Susanto Ahmad. 2014. Teori Belajar dan Pembelajaran di Sekolah Dasar. Jakarta: Kencana Prenadamedia Group.

Undang-Undang Republik Indonesia Nomor 20 Pasal 40 tentang Kewajiban Tenaga Kependidikan. 2003. Jakarta: Permendiknas.

Yulanda, L., \& Zafri. (2019). Pemanfaatan Aplikasi Plickers pada Mata Pelajaran Sejarah Kelas X SMAN 01 XI Nagari Bayang Utara. Jurnal Kapita Selekta Geografi, 2(4), 54-77. 